\title{
THE EFFECT OF MARKET ORIENTATION ON BUSINESS PERFORMANCE OF SERBIAN ORGANIC PRODUCERS
}

\author{
Semir Vehapi ${ }^{1}$, Marina Milanović ${ }^{2}$
}

\begin{abstract}
Summary
In the current conditions, market orientation plays a vital role in the generation of superior performances and the achievement of a competitive advantage. Even though the concept of market orientation was evaluated in various studies, there are very few such studies in the context of the Serbian economy, and in the organic food industry there are almost none. Thus the basic aim of this paper is to examine the degree of practicing market orientation in the businesses of Serbian organic food producers, and to identify a connection between their market orientation and business performance. In the paper we applied a cultural perspective in the measuring of market orientation by using the MKTOR scale as a basis. On a sample of 42 surveyed producers, it was confirmed that the elements of market orientation directly and positively affect sales growth, market share and profitability, as well as overall business performance.
\end{abstract}

Key words: market orientation, business performance, producers, organic food, Serbia.

JEL: $M 31, Q 13, L 66$

\section{Introduction}

At a time marked by constant changes in consumer preferences, rapid technicaltechnological development and increasing rivalry among competitors, it is becoming essential for companies to develop an effective mechanism for reacting to market changes which in market literature is known as market orientation (MO). Goldman and Grinstein (2010) indicate that MO is becoming a crucial strategy for realizing and maintaining a competitive advantage in an unstable business environment. According to most authors MO represents an implementation of marketing concepts (Kohli \& Jaworski, 1990; Deng \& Dart 1994; Gray, Matear, Boshoff, \& Matheson, 1998;

1 Semir Vehapi, Ph.D., Assistant, State University of Novi Pazar, Department of Economic Sciences (office no. 23), Vuka Karadzica Street nn, 36300 Novi Pazar, Republic of Serbia, Phone: +381638618 381, E-mail: svehapi@np.ac.rs

2 Marina Milanović M.A., Ph.D. student, University of Niš, Faculty of Economics, 84 Dr Jovana Risitća Street, 34000 Kragujevac, Phone: +381659393777 E-mail: milanovicm. ar67@gmail.com

EP 2017 (64) 4 (1651-1668) 
Appiah-Adu, 1998a; Appiah-Adu \& Singh, 1998; Lafferty \& Hult, 2001; Guo, 2002; Caruana, Pitt, \& Ewing, 2003; Agarwal, Krishna Erramilli, \& Dev, 2003). However, laying the foundations for MO is not easy or simple. Namely, different authors writing from various stand point are studying the aforementioned phenomenon, which as a result leads to various definitions of the same concept. Two dominant approaches to the conceptual determination and measuring of MO stem from the work of Narver and Slater (1990), and Kohli and Jaworski (1990). According to Narver and Slater (1990), MO consists of three behavioral components: consumer orientation, competitor orientation and interfunctional coordination, and two decision criteria: long-term focus and profitability. Consumer orientation includes knowing the current and future needs of consumers in the target market so that the organization is able to continually deliver superior value to them. Competitor orientation refers to the monitoring and understanding of short-term strengths and weaknesses of the competition as well as their long-term abilities and strategies. Interfunctional coordination represents the coordinated use of all available resources of the organization in the creation of superior value for target consumers (Narver \& Slater, 1990). According to the second approach, advocated by Kohli and Jaworski (1990) MO has three very important aspects: (1) generating market intelligence which includes the collection of information on the market; (2) spreading market intelligence horizontally and vertically in the organization; and (3) a response in the form of concrete activities taken by organizations in accordance with the market conditions. The definition of Kohli and Jaworski is based on the behavioral dimension of interpretation of MO, while Narver and Slater base their definition on the cultural dimension of an organization. Despite a distinctive difference, these two interpretations of MO share certain similarities. In both cases scientists point out that an important aspect of MO is the gathering of information from consumers and competitors and emphasize the importance of collective effort in the creation of value for consumers (Julian, Mohamad, Ahmed, \& Sefnedi, 2014). However, Nerver and Slater (1990) are better at comprehending the essence of the marketing concept, including in the concept of MO all the bearers of marketing concepts and emphasizing the long-term perspective of acquiring profit. From that point of view, the approach of Narver and Slater could be considered a more encompassing one. This approach is taken as the starting point in studying the effect of $\mathrm{MO}$ on business performances in this paper.

Irrespective of the different viewpoints on $\mathrm{MO}$, it is certain that $\mathrm{MO}$ is necessary in business management and administration for the increase in business performance (Levitt, 2004). Companies use MO with the aim of achieving a competitive advantage and superior business performance (Li, Zhou, Mo, Yang, \& An, 2009). Authors who have studied the consequences of MO agree that it has a positive influence on the business performance of the organization (Ruekert, 1992; Jaworski \& Kohli, 1993; Deshpande, Farley, \& Webster, 1993; Raju, Lonial, \& Gupta, 1995; Rodriguez Cano, Carrillat, \& Jaramillo, 2004; Kirca, Jayachandran, \& Bearden, 2005; Ellis, 2006; Panigyrakis \& Theodoridis, 2007; Olavarrieta \& Friedmann. 2008; Morgan, Vorhies, \& Mason, 2009; Liao, Chang, Wu, \& Katrichis, 2011; Ngo \& O'Cass, 2012; Gruber-Muecke \& 
Hofer, 2015), and especially on financial performance (Narver \& Slater, 1990; Dawes, 2000; Shoham, Rose, \& Kropp, 2005; Haugland, Myrtveit, \& Nygaard, 2007; Chao \& Spillan, 2010; Rapp, Beitelspacher, Schillewaert, \& Baker, 2012). Pelham and Wilson (1996, 1997a, 1997b, 1999) in several successive studies indicate the existence of a positive connection between MO and business performance at the level of small and medium sized enterprises, while Salavou (2002) does the same in his research, which includes small and medium sized enterprises, but within the food and beverage industry. Most of these studies on the effects of MO were carried out in developed countries. However, the positive influence of $\mathrm{MO}$ on business performance has been found in transition economies as well (Hooley et al., 2000; Protcko \& Dornberger, 2014). In Serbia, empirical studies in this field are still too few considering that a very small number of authors dealt with $\mathrm{MO}$ and its effect on business performance (Milisavljević, 2005; Stanković, Đukić, \& Popović, 2013). This was the first important motive for carrying out this research. The second motive was based on the huge market potential of organically produced food.

The global organic food market has undergone rapid growth over the past two decades. This market, in the period between 1999-2015 increased four times, achieving a value of 81.6 billion dollars in 2015. The demand for organic food is most prominent in North America and Europe, which together generate $90 \%$ of the overall global sales of these products. The greatest per-capita consumption was noted in Switzerland (262€), Denmark (191€) and Sweden (177€). And while developed countries appear to dominate the demand for organic food, undeveloped countries and developing countries have the opportunity to become significant producers and exporters of organic products. Most of the producers of organic food are to be found in countries such as India (585'200), Ethiopia (203'602) and Mexico (200'039) (Willer \& Lernoud, 2017). In Serbia, which can in terms of organic food be considered an emerging market, there is a significantly smaller number of producers. Namely, during 2015 there were 300 registered organic food producers and processors. The methods of organic production are implemented on approximately 15'298 ha, which makes up only $0.4 \%$ of the overall agricultural land. This production capacity is in agreement with the current level of organic food consumption on the national market. The overall turnover in the organic food sector in Serbia was estimated at US\$ 40 million, while the average annual expenditures was 5 dollars per capita (Willer \& Lernoud, 2014, 2017). A deeper understanding of MO and understanding of its role in the business success of the organization can lead to the increase in the number of market oriented organic food producers and thus provide quicker development of the national market. In addition, the development and application of MO in the businesses of organic producers creates the conditions for the expand of this concept in sustainable MO (Mitchell, Wooliscroft, \& Higham, 2010). 


\section{Research methodology}

\section{Hypotheses and conceptual framework}

Bearing in mind the fact that the implementation of $\mathrm{MO}$ in business contributes to a better understanding of the market, the aim that was set in the research was to study and evaluate the degree of $\mathrm{MO}$ in the businesses of Serbian organic food producers, and to identify the connection between their $\mathrm{MO}$ and business performances. During the realization of this type of goal, we formed the following hypotheses:

H1: A higher level of MO in business has a positive influence on the growth in sales;

$\mathrm{H} 2$ : A higher level of MO in business has a positive influence on the market share;

H3: A higher level of MO in business has a positive influence on profitability;

H4: A higher level of MO in business has a positive effect on the overall business performance.

In accordance with the defined hypotheses, we developed a conceptual framework which consists of an independent and dependent variable. MO represents the independent variable, while the dependent variable is manifested through the indicators of business performance (Fig. 1). The relations among the variables which are hypothesized in this research differ from those which have been indicated in the literature to date. Namely, most of the previous studies focused on the indirect relationship between MO and business performance, including different mediating variables and/or environmental moderators which can influence the strength of this connection (Kohli \& Jaworski, 1990; Jaworski \& Kohli, 1993; Slater \& Narver, 1994; Appiah-Adu1998b; MaydeuOlivares \& Lado, 2003; Kirca et al., 2005; Olavarrieta \& Friedmann, 2008; Johnson, Dibrell, \& Hansen, 2009; Raju, Lonial, \& Crum, 2011; Takata, 2016). Contrary to that, this research deals with the direct effect of $\mathrm{MO}$ on business performance.

Figure 1. The conceptual framework of the connection between MO and business performance

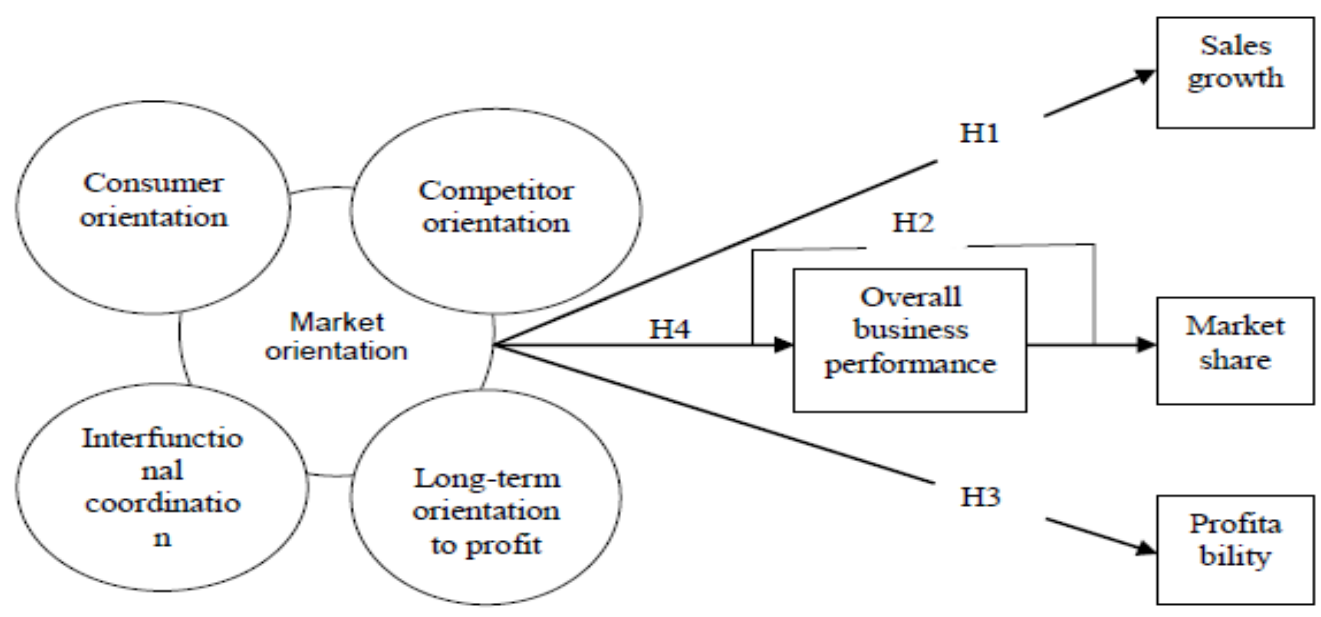




\section{Questionnaire development and measures}

The research presented in this paper is based on the findings obtained through quantitative analyses, through the means of a survey questionnaire. The measuring instrument used was the structured questionnaire which included 28 questions grouped into three segments. The first group of questions was aimed at studying the intensity of the application of MO in the businesses of domestic organic food producers (14 questions). The second group of questions is focused on measuring the business performance of producers (4 questions), while the third group of questions is formulated with the intention of discovering the basic data and characteristics of Serbian organic food producers (10 questions). All of the questions are represented in the form of closed-end questions with multiple-choice answers and a five-point scale.

Based on the two main approaches in the evaluation of the MO, two different scales for the evaluation of MO emerge: MKTOR (Narver \& Slater, 1990) and MARKOR (Kohli, Jaworski, \& Kumar, 1993). MO in this study is measured by a scale which is adjusted to suit the MKTOR scale. The reason for opting for the MKTOR scale lies in its suitability for measuring MO on different and heterogeneous markets (Hooley et al., 2000), which makes it an appropriate scale for measuring MO of transition countries, including Serbia. The scale included 14 items, 5 of which were used to measure consumer orientation, 3 to measure competitor orientation, 4 to measure interfunctional coordination and 2 items to measure the long-term orientation towards profit (table 1). The intensity of the items of MO was measured on a five-point Likert scale. The respondents through their answers indicated the extent to which they agreed with the statements on the practices of MO in their businesses. The scale ranges from 1 which means "I completely disagree" to 5 which means "I completely agree".

Table 1. The scale used to measure MO

\begin{tabular}{|l|l|}
\hline No. & Items \\
\hline 1 & Information on competitors is regularly gathered. \\
\hline 2 & Our strategic goals and policies are directly aimed at client satisfaction. \\
\hline 3 & The level of client satisfaction is regularly evaluated. \\
\hline 4 & $\begin{array}{l}\text { Our organization differentiates our market offer in relation to the differences in the needs and } \\
\text { requirements of various clients. }\end{array}$ \\
\hline 5 & $\begin{array}{l}\text { Our organization is focused on building close and strong relationships with our most important } \\
\text { clients. }\end{array}$ \\
\hline 6 & Information on competitors is regularly gathered. \\
\hline 7 & $\begin{array}{l}\text { The comparison of our offer and the offer of our most important competitors is regularly } \\
\text { performed. }\end{array}$ \\
\hline 8 & Our organization rapidly responds to any activities of our competitors. \\
\hline 9 & Long-term orientation to profit is a characteristic of our organization. \\
\hline 10 & $\begin{array}{l}\text { Improvement in market performance is equally important as the improvement of internal } \\
\text { effectiveness. }\end{array}$ \\
\hline 11 & $\begin{array}{l}\text { Information on clients is transferred to all the departments and all the functions of the } \\
\text { organization. }\end{array}$ \\
\hline 12 & All the departments in the organization work on satisfying client needs. \\
\hline
\end{tabular}




\begin{tabular}{|l|l|}
\hline No. & Items \\
\hline 13 & The structure of our organization is flexible and enables better client services. \\
\hline 14 & Rewarding employees is connected with market performance and client satisfaction. \\
\hline
\end{tabular}

Source: adapted from: Narver and Slater (1990)

Measuring business performance requires the differentiation between two basic principles. The first is the objective approach is based on absolute measures, while the other is a subjective approach which primarily takes into consideration performance in relation to competitors or expectations. In this research we relied on a subjective approach where the respondents were asked to rate their business performance over the last three years in relation to their expectations, on a scale from 1 to 5 (1- very poor, 5 - excellent). A subjective approach was selected due to the difficulties in gathering objective data. The measuring included four indicators:

- $\quad$ the market share (Narver \& Slater, 1990; Ruekert, 1992; Jaworski \& Kohli, 1993; Greenley \& Foxall, 1997, 1998);

- sales growth (Narver \& Slater, 1990; Ruekert, 1992; Slater \& Narver 1994; Greenley \& Foxall, 1997, 1998);

- $\quad$ profitability (Greenley and Foxall, 1997, 1998); and

- overall business performance (Kohli \& Jaworski, 1990).

The market share was selected since it is a measure based on consumers and is an important indicator in evaluating the performance of the food industry, while increase in growth and profitability are included due to their importance in evaluating organizational effectiveness and efficiency (Gladson Nwokah, 2008, p. 282).

\section{Sampling and data collection}

The target population in the research were registered organic food producers on the territory of the Republic of Serbia. The size of the population was determined by the number of producers which were included in the publically available records of the Ministry of Agriculture and Environmental Protection on producers included in organic food production with a permit to produce issued by verified control organizations for 2012, and the list included 1061 producers. Due to financial and logistic obstacles ${ }^{3}$ this study could not focus on all the subjects of the target population. Thus the research was carried out on a simple random sample which included 41 producers. The sample predominantly consists of a small sized of producers $(56.1 \%)$ organized primarily in the form of limited liability organizations $(48.8 \%)$ and family farms $(41.5 \%)$ with a majority local capital (95.1\%). The largest number of production units $(56.1 \%)$ can be found on the territory of Vojvodina which might be considered the main zone of production (table 2).

3 The main obstacle is that most producers have the status of cooperatives and are contractually bound to a particular company - which then buys their entire stock. 
Table 2. The structure of the sample based on geographic location, the type of organization, origin of capital and size of the organization

\begin{tabular}{|c|c|c|}
\hline Category & $\begin{array}{l}\text { Absolute frequency } \\
(\%)\end{array}$ & $\begin{array}{c}\text { Relative frequency } \\
(\%)\end{array}$ \\
\hline \multicolumn{3}{|l|}{ Number of employees } \\
\hline 2-9 employees & 12 & 29.3 \\
\hline 10-49 employees & 23 & 56.1 \\
\hline 50-249 employees & 5 & 12.2 \\
\hline Over 250 employees & 1 & 2.4 \\
\hline \multicolumn{3}{|l|}{ Origin of capital } \\
\hline Mostly local capital & 39 & 95.1 \\
\hline Mostly foreign capital & 2 & 4.9 \\
\hline \multicolumn{3}{|l|}{ Type of organization } \\
\hline Family farm & 17 & 41.5 \\
\hline Limited liability organization & 20 & 48.8 \\
\hline Stock company & 1 & 2.4 \\
\hline Agricultural cooperative & 0 & 0 \\
\hline Entrepreneur & 2 & 4.9 \\
\hline $\begin{array}{l}\text { Educational and research facility which deals with } \\
\text { agricultural production }\end{array}$ & 1 & 2.4 \\
\hline \multicolumn{3}{|l|}{ Geographic location of the organization } \\
\hline Vojvodina & 23 & 56.1 \\
\hline Belgrade & 8 & 19.5 \\
\hline Šumadijaand West Serbia & 5 & 12.2 \\
\hline South and South-East Serbia & 5 & 12.2 \\
\hline Kosovo and Metohija & 0 & 0 \\
\hline Overall & 41 & $100 \%$ \\
\hline
\end{tabular}

Source: The data which the author obtained in his own field work

Afurther analysis of the national organic producers reveals other important characteristics of their business. Namely, most of the sample consists of producers whose production has organic status $(58.5 \%)$, while only $28 \%$ are undergoing the process of conversion. The greatest number of respondents have been involved in this type of production for 3-5 years (34.1\%), and only a few of them have been involved in organic production for longer than one decade (12.2\%). This only confirms the fact that in Serbia, organic production is still in its initial phase of development. The surveyed producers mainly decide to practice both organic and conventional production at the same time $(61 \%)$. The food processing industry in the national organic food sector indicates a slight improvement which is supported by the significant percentage of surveyed producers who are also involved in the production and processing of organic products $(63.4 \%)$. In the case of the structure of production, $68.3 \%$ of the respondents produce plant products and only $12.2 \%$ produce animal products. With such a structure of production, the greatest number of producers is oriented towards the regional market $(48.8 \%)$ and national market (31.7\%). 
For the realization of the goals of the research we combined an online interview and a personal interview. The questionnaire was first prepared in electronic form and distributed to approximately 120 randomly selected addresses of producers. One part of the email addresses was obtained through the National Association for Development of Organic Production "Serbia Organica", while the other addresses were collected by browsing the internet presentations of producers as well as through telephone contacts. Considering that the response rate was low and made up only $10 \%$, the email survey was extended to include a personal interview carried out at the $81^{\text {st }}$ International Agricultural Fair held in Novi Sad ${ }^{4}$. The fair participants, who were also included in the sample, were chosen randomly, so that the personal interview included 29 producers. The overall survey lasted from May 8 until June 3, 2014, at which point the survey procedure ended.

\section{Data analysis}

The obtained data were processed using SPSS 21 (Statistical Program for Social Science) computer software. The used data processing methods included descriptive and analytical statistical methods. The applied descriptive measures included relative numbers, central tendency measures (means) and dispersion measures (standard deviation). The reliability of the measuring scales was determined using Cronbach's alpha coefficient. In order to study the statistical significance between the categories of variables, we carried out a correlation analysis. The level of probability was considered statistically significant at the level $<0.05$.

\section{Research findings and discussion Results of realiability analysis}

When carrying out the research care must be taken that the scales of measurement are reliable, that is, that there is internal scale consistency. The internal consistency of the items was measured using Cronbach's alpha coefficient. The value of this coefficient ranges from 0-1, where the acceptable values are all the values above 0.70 (Pallant, 2011). The value of Cronbach's alpha coefficient for $\mathrm{MO}$ is 0.908 , and for business performance is 0.879 . The obtained values by far exceed the borderline values, which indicates adequate reliability and internal consistency of the manifested variables.

\section{The descriptive statistics}

Once the internal consistency of the scale was evaluated, an analysis of the descriptive statistics of the scales which make up the conceptual framework was carried out. The means and standard deviation were used in the analysis. The analysis of the items within the $M O$ scale indicates that the item "Our organization is focused on building close and strong relationships with our most important clients" is most pronounced, that is, that most of the participants agree with it ( $\mathrm{AS}=4.61)$. Contrary to that, the item "The level of client

4 The $81^{\text {st }}$ International Agricultural Fair was held from May 20-26, 2014 
satisfaction is regularly evaluated" is one that the participants agreed with the least (AS = 3.34). The means for the items which make up the MO scale lead us to the conclusion that in the case of producers, generally there is a moderate to high level of MO.

Within the Business performance scale, the participants singled out sales growth as the indicator of performance which the most satisfied their expectations in the last three years (AS = 3.51). On the other hand, profitability is the weakest ranked indicator of business performance (AS = 3.37) (table 5). However, the difference between the means of sales growth and the means of profitability is negligibly small, which indicates that the producers are generally satisfied with the achieved growth in sales, but also the other indicators of performance (market share, profitability and overall performance) over the past three years.

\section{The results of the normality of distribution test}

The normality of distribution was studied using the Kolmogorov-Smirnov and ShapiroWilk tests. Considering that the sample is $<50$ the results of the Shapiro-Wilk test were included in the analysis. The results indicate that the Shapiro-Wilk tests are statistically significant (table 3), so the null hypothesis that the distribution is not normal is accepted. Thus, we can conclude that the given variables do not have normal distribution.

Table 3. Testing the normality of distribution

\begin{tabular}{|l|l|l|l|l|l|l|}
\hline \multirow{2}{*}{ Variables } & \multicolumn{4}{l}{ Kolmogorov-Smirnov } & \multicolumn{3}{l|}{ Shapiro-Wilk } \\
\cline { 2 - 8 } & Statistic & $\mathbf{d f}$ & $\mathbf{p}$ & Statistic & $\mathbf{d f}$ & $\mathbf{p}$ \\
\hline MO & .163 & 41 & .008 & .889 & 41 & .001 \\
\hline Sales growth & .238 & 41 & .000 & .889 & 41 & .001 \\
\hline Market share & .258 & 41 & .000 & .882 & 41 & .000 \\
\hline Profitability & .282 & 41 & .000 & .808 & 41 & .000 \\
\hline Overall business performance & .288 & 41 & .000 & .813 & 41 & .000 \\
\hline
\end{tabular}

Source: Authors' calculations

\section{Results of the correlation analysis}

The correlation analysis was carried out to determine whether there is a connection between MO and business performance as the basic variables of the initial model, as well as to determine its strength and direction. Considering that the basic assumption of Pearson's correlation was not satisfied, the one which refers to the normality of distribution, in this case the connection was studied using Spearman's rank correlation coefficient (ro). According to Petz (2004), a rough approximations of the extent of the connection, that is, Spearman correlation coefficient (ro) is: a) from \pm 0.00 to \pm 0.20 a weak or slight correlation; b) from \pm 0.20 to \pm 0.40 a middle correlation; c) from \pm 0.40 to \pm 0.70 a significant correlation; and d) \pm 0.70 to \pm 1 high or very high correlation.

There is a statistically significant positive correlation between $\mathrm{MO}$ of the organization and the increase in the volume of its sales, $\mathrm{ro}=0.388, \mathrm{n}=41, \mathrm{p}<0.012$ (middle correlation). A more EP 2017 (64) 4 (1651-1668) 
detailed analysis indicates that there is a statistically significant correlation between the sales growth of the organization on the one hand and the following statements: Long-term orientation to profit is a characteristic of our organization (a significant correlation), Our organization is focused on building of close and strong relationships with our most important clients (a significant correlation), Information on clients is transferred to all the departments and to all the functions of the organization (a significant correlation), Information on competitors is regularly gathered (a middle correlation), All of the departments in the organization work on satisfying client needs (a middle correlation), Our organization differentiates our market offer in relation to differences in the needs and requirements of various clients (middle correlation) and Rewarding employees is connected with market performance and client satisfaction (middle correlation) (table 4, column 3). All of the statistically significant correlations are positive, which means that with an increase in the value of one, there is an increase in the value of the other variable. The order of the statements is determined based on the intensity of the correlation. Therefore, hypothesis $\mathrm{H} 1$ has been confirmed.

There is a statistically significant positive correlation between the MO of a business and its market share, $\mathrm{ro}=0.319, \mathrm{n}=41, \mathrm{p}<0.042$ (middle correlation). A more detailed analysis indicates that there is a statistically significant correlation between the market share of an organization on the one hand and the following statements: Improvement in market performance is equally important as the improvement of internal effectiveness (a middle correlation), Information on competitors is regularly gathered (middle correlation) and All the departments in the organization work on satisfying client needs (middle correlation). All of the statistically significant correlations are positive (table 4, column 4). Thus, the hypothesis that a higher level of $\mathrm{MO}$ of the organization has a positive influence on its market share.

There is a statistically significant positive correlation between $\mathrm{MO}$ of the organization and its profitability, $\mathrm{ro}=0.456, \mathrm{n}=41, \mathrm{p}<0.003$ (a significant correlation). A more detailed analysis indicates that there is a statistically significant correlation between profitability of the organization on the one hand and the following statements: Information on clients is transferred to all the departments and to all the functions of the organization (a significant correlation), Long-term orientation to profit is a characteristic of our organization (a significant correlation), Information on competitors is regularly gathered (a middle correlation), Our strategic goals and policies are directly focused on the building client satisfaction (a middle correlation), Information on client needs and requirements is regularly gathered (a middle correlation), Our organization is focused on the building of close and strong relationships with our most important clients (a middle correlation), All of the departments in the organization work on satisfying client needs (a middle correlation) and Our organization rapidly responds to any activities of our competitors (a middle correlation). All of the statistically significant correlations are positive (table 4, column 5). Based on that, we have confirmed the hypothesis that a higher level of MO has a positive influence on its profitability.

There is a statistically significant positive correlation between $\mathrm{MO}$ and the overall business performance, $\mathrm{ro}=0.379, \mathrm{n}=41, \mathrm{p}<0.015$ (a middle correlation). A more detailed analysis indicates that there is a statistically significant correlation between business 
performance on the one hand and the following statements: Information on competitors is regularly gathered (a significant correlation), Our organization differentiates our market offer in relation to the differences in the needs and requirements of various clients (a middle correlation), The level of client satisfaction is regularly evaluated (a middle correlation), The comparison of our offer and the offer of our most important competitors is regularly performed (a middle correlation) and Improvement in market performance is equally important as the improvement of internal effectiveness (a middle correlation). All of the statistically significant correlations are positive (table 4, column 6). Once again we proved the hypothesis that the higher level of MO has a positive effect on overall business performance.

Table 4. The correlation between MO and indicators of business performance

\begin{tabular}{|c|c|c|c|c|c|}
\hline & & $\begin{array}{c}\text { Sales } \\
\text { growth }\end{array}$ & $\begin{array}{c}\text { Market } \\
\text { share }\end{array}$ & Profitability & $\begin{array}{c}\text { Overall } \\
\text { performance }\end{array}$ \\
\hline \multirow{2}{*}{ MO } & ro & $.388 *$ & $.319 *$ & $.456 * *$ & $.379 *$ \\
\hline & $\mathrm{p}$ & .012 & .042 & .003 & .015 \\
\hline \multicolumn{6}{|l|}{ Items of $M O$} \\
\hline \multirow{2}{*}{$\begin{array}{l}\text { Information on client needs } \\
\text { and requirements is regularly } \\
\text { gathered. }\end{array}$} & ro & .118 & .197 & $.361 *$ & .287 \\
\hline & $\mathrm{p}$ & .463 & .217 & .021 & .069 \\
\hline \multirow{2}{*}{$\begin{array}{l}\text { Our strategic goals and policies } \\
\text { are directly aimed at client } \\
\text { satisfaction. }\end{array}$} & ro & .252 & .304 & $.368 *$ & .302 \\
\hline & $\mathrm{p}$ & .112 & .053 & .018 & .055 \\
\hline \multirow{2}{*}{$\begin{array}{l}\text { The level of client satisfaction } \\
\text { is regularly evaluated. }\end{array}$} & ro & .211 & .159 & .090 & $.351 \%$ \\
\hline & $\mathrm{p}$ & .185 & .321 & .575 & .024 \\
\hline \multirow{2}{*}{$\begin{array}{l}\text { Our organization differentiates } \\
\text { our market offer in relation to } \\
\text { the differences in the needs and } \\
\text { requirements of various clients. }\end{array}$} & ro & $.360 *$ & .184 & .263 & $.373 *$ \\
\hline & $\mathrm{p}$ & .021 & .249 & .096 & .016 \\
\hline \multirow{2}{*}{$\begin{array}{l}\text { Our organization is focused } \\
\text { on building close and strong } \\
\text { relationships with our most } \\
\text { important clients. }\end{array}$} & ro & $.461 *$ & .308 & $.358 *$ & .204 \\
\hline & $\mathrm{p}$ & .002 & .050 & .022 & .202 \\
\hline \multirow{2}{*}{$\begin{array}{l}\text { Information on competitors is } \\
\text { regularly gathered. }\end{array}$} & ro & $.378 *$ & $.352 *$ & $.377 *$ & $.434 * *$ \\
\hline & $\mathrm{p}$ & .015 & .024 & .015 & .005 \\
\hline \multirow{2}{*}{$\begin{array}{l}\text { The comparison of our offer } \\
\text { and the offer of our most } \\
\text { important competitors is } \\
\text { regularly performed. }\end{array}$} & ro & .088 & .151 & .255 & $.343 *$ \\
\hline & $\mathrm{p}$ & .583 & .347 & .108 & .028 \\
\hline \multirow{2}{*}{$\begin{array}{l}\text { Our organization rapidly } \\
\text { responds to any activities of our } \\
\text { competitors. }\end{array}$} & ro & .058 & .056 & $.339 \%$ & .269 \\
\hline & $\mathrm{p}$ & .718 & .726 & .030 & .090 \\
\hline
\end{tabular}




\begin{tabular}{|c|c|c|c|c|c|}
\hline & & $\begin{array}{c}\text { Sales } \\
\text { growth }\end{array}$ & $\begin{array}{c}\text { Market } \\
\text { share }\end{array}$ & Profitability & $\begin{array}{c}\text { Overall } \\
\text { performance }\end{array}$ \\
\hline \multirow{2}{*}{$\begin{array}{l}\text { Long-term orientation to } \\
\text { profit is a characteristic of our } \\
\text { organization. }\end{array}$} & ro & $.444 * *$ & .234 & $.427 * *$ & .203 \\
\hline & $\mathrm{p}$ & .004 & .141 & .005 & .204 \\
\hline \multirow{2}{*}{$\begin{array}{l}\text { Improvement in market } \\
\text { performance is equally } \\
\text { important as the improvement } \\
\text { of internal effectiveness. }\end{array}$} & ro & .145 & $.383 *$ & .142 & $.319 *$ \\
\hline & $\mathrm{p}$ & .366 & .014 & .377 & .042 \\
\hline \multirow{2}{*}{$\begin{array}{l}\text { Information on clients } \\
\text { is transferred to all the } \\
\text { departments and all the } \\
\text { functions of the organization. }\end{array}$} & ro & $.425 * *$ & .231 & $.439 * *$ & .192 \\
\hline & $\mathrm{p}$ & .006 & .146 & .004 & .229 \\
\hline \multirow{2}{*}{$\begin{array}{l}\text { All of the departments in the } \\
\text { organization work on satisfying } \\
\text { client needs. }\end{array}$} & ro & $.366 \%$ & $.325 \%$ & $.357 *$ & .247 \\
\hline & $\mathrm{p}$ & .019 & .038 & .022 & .119 \\
\hline \multirow{2}{*}{$\begin{array}{l}\text { The structure of our } \\
\text { organization is flexible and } \\
\text { enables better client services. }\end{array}$} & ro & .160 & .229 & .274 & .217 \\
\hline & $\mathrm{p}$ & .316 & .150 & .083 & .172 \\
\hline \multirow{2}{*}{$\begin{array}{l}\text { Rewarding employees is } \\
\text { connected with market } \\
\text { performance and client } \\
\text { satisfaction. }\end{array}$} & ro & $.352 \%$ & .258 & .172 & .257 \\
\hline & $\mathrm{p}$ & .024 & .103 & .283 & .104 \\
\hline
\end{tabular}

Source: Authors' calculations

\section{Conclusion - implication, limitations and future research directions}

This study provides empirical evidence that MO of organic food producers has a positive effect on their business performance. The positive effect of MO on selected indicators of performance has been confirmed for all the indicators of performance (sales growth, profitability and the market share) as well as the overall business performance. At the same time, the strongest positive influence of MO is realized on profitability, and the weakest influence on sales growth. Of the individual items of $\mathrm{MO}$, the most significant ones for the improvement of business performance are the following: Information on the competitors is regularly gathered, Our organization is focused on building close and strong relationships with our most important clients, Information on clients is transferred to all the departments and all the functions of the organization and Longterm orientation to profit is a characteristic of our organization. This indicates that customer orientation, competitor orientation and interfunctional coordination are equally important dimensions of $\mathrm{MO}$, while long-term profitability is the ultimate goal of market orientated companies. 
The results of this research could aid organic food producers in Serbia to realize the importance of $\mathrm{MO}$ as a key factor of performance improvement. The producers should first attempt to continually gather information on the needs and requirements of current and potential consumers. What is more, producers should rate the satisfaction of their clients regularly, and care for their clients even after the completion of sales and provision of services. In addition, management should gather information on direct and indirect competitors, at the same time monitoring their activities, strategies and products. The essential information on clients and competitors needs to be distributed through all the levels of the organization. During regular staff meetings, the obtained information on clients and competitors could be analyzed, and news ways of organizing responses to current market information could be suggested. If the organization were to respond by providing greater value to the clients than the competitors, it could acquire the favor of and trust of the clients. Loyal consumers usually return to purchase once again and become immune to the pressure of competitors thereby generating increased sales for the organization. The result is an increase in the market share. Greater sales growth and a greater market share in comparison to the competitors leads to greater income and thus greater potential profitability.

In addition to its significant contribution to the improvement of management theory and practice, the empirical study has several limitations which do not significantly diminish the quality of the obtained results. The first potential limitation of the research results is the knowledge that the questionnaire might have been completed by individuals who are not in charge of marketing, which might be a consequence of the choice of an online survey. The second potential limitation refers to the fact that no moderating variables were included in the study on the connection between $\mathrm{MO}$ and business performance. Thirdly, there is the possibility that the surveyed producers, with or without the intention of being prejudiced in offering responses, evaluating the claims in the questionnaire by overestimating their market power. The limitation of this, as well as most other studies, lies in the lack of any monitoring of marketing activities of producers over time. Finally, a relatively small sample could limit the validity of the conclusions drawn in relation to the research questions.

Based on existing research and the previously cited limitations, in this study we suggested several possible directions for future research. Mainly, the connection between MO and business performance should be studied over a period of time exceeding three years, which made up the studied interval of business performance in this study. Along with the development of the organic food market, the connection between MO and business performance should be studied and analyzed in a wider context. This means that the goal of upcoming research should be to study factors which could be moderators of the influence of $\mathrm{MO}$ on the business performance of organizations. In the case of business performance, there is much room for further research both in the selection of the measures of performance and the means of their measuring. Starting from a multidimensionality in performance, we should take into consideration the inclusion of other nonfinancial measures of performance which could help in the evaluation of short- 
term results. In addition, further studies might include both objective and subjective approaches to measuring performance. This certainly includes the public being allowed access to financial reports of the analyzed organizations.

\section{Literature}

1. Agarwal, S., Krishna Erramilli, M. and Dev, C. S. (2003). Market orientation and performance in service firms: role of innovation, Journal of Services Marketing, Vol. 17, No. 1, pp. 68-82.

2. Appiah-Adu, K. (1998a). Market orientation and performance: empirical tests in a transition economy, Journal of Strategic Marketing, Vol. 6, No. 1, pp. 25-45.

3. Appiah-Adu, K. (1998b). Market Orientation and Performance: Do the Findings Established in Large Firms Hold in the Small Business Sector? Journal of Euromarketing, Vol. 6, No. 3, pp. 1-26.

4. Appiah-Adu, K. and Singh, S. (1998). Customer orientation and performance: a study of SMEs, Management Decision, Vol 36, No. 6, pp. 385-394.

5. Caruana, A., Pitt, L. and Ewing, M. (2003). The market orientation-performance link: the role of service reliability, The Service Industries Journal, Vol. 23 No. 4, pp. 25-41.

6. Chen-Ho Chao, M. and Spillan, J. E. (2010). The journey from market orientation to firm performance, Management Research Review, Vol. 33, No. 5, pp. 472-483.

7. Dawes, J. (2000). Market Orientation and Company Profitability: Further Evidence Incorporating Longitudinal Data, Australian Journal of Management, Vol. 25, No. 2.

8. Deng, S. and Dart, J. (1994). Measuring market orientation: A multi-factor, multiitem approach, Journal of Marketing Management, Vol.10, No. 8, pp. 725-742.

9. Deshpande, R., Farley, J. U. and Webster, F. E. (1993). Corporate Culture, Customer Orientation, and Innovativeness in Japanese Firms: A Quadrad Analysis, Journal of Marketing, Vol. 57 No. 1, pp. 23-37.

10. Ellis, P. D. (2006). Market Orientation and Performance: A Meta-Analysis and Cross-National Comparisons, Journal of Management Studies, Vol. 43, No. 5, pp. 1089-1107.

11. Gladson Nwokah, N. (2008). Strategic market orientation and business performance, European Journal of Marketing, Vol. 42, No. 3/4, pp. 279-286.

12. Goldman, A. and Grinstein, A. (2010). Stages in the development of market orientation publication activity, European Journal of Marketing, Vol. 44, No. (9/10), pp. 1384-1409.

13. Gray, B., Matear, S., Boshoff, C. and Matheson, P. (1998). Developing a better measure of market orientation, European Journal of Marketing, Vol. 32, No. 9/10, pp. 884-903.

14. Greenley, G. E. and Foxall, G. R. (1997). Multiple Stakeholder Orientation in UK Companies and the Implications for Company Performance, Journal of Management Studies, Vol. 34, No. 2, pp. 259-284. 
15. Greenley, G. E. and Foxall, G. R. (1998). External moderation of associations among stakeholder orientations and company performance, International Journal of Research in Marketing, Vol. 15, No. 1, pp. 51-69.

16. Gruber-Muecke, T. and Hofer, K. M. (2015). Market orientation, entrepreneurial orientation and performance in emerging markets, International Journal of Emerging Markets, Vol. 10, No. 3, pp. 560-571.

17. Guo, C. (2002). Market orientation and business performance, European Journal of Marketing, Vol. 36, No. 9/10, pp. 1154-1163.

18. Haugland, S. A., Myrtveit, I. and Nygaard, A. (2007). Market orientation and performance in the service industry: A data envelopment analysis, Journal of Business Research, Vol. 60, No. 11, pp. 1191-1197.

19. Hooley, G., Cox, T., Fahy, J., Shipley, D., Beracs, J., Fonfara, K. and Snoj, B. (2000). Market Orientation in the Transition Economies of Central Europe, Journal of Business Research, Vol. 50, No. 3, pp. 273-285.

20. Jaworski, B. J. and Kohli, A. K. (1993). Market Orientation: Antecedents and Consequences, Journal of Marketing, Vol. 57, No. 3, pp. 53-70.

21. Johnson, A. J., Dibrell, C. C. and Hansen, E. (2009). Market Orientation, innovativeness, and Perfomance of Food Companies, Journal of Agribusiness, Vol. 27, No. 1/2, pp. 85-106.

22. Julian, C. C., Mohamad, O., Ahmed, Z. U. and Sefnedi, S. (2014). The Market Orientation-Performance Relationship: The Empirical Link in Export Ventures, Thunderbird International Business Review, Vol. 56, No. 1, pp. 97-110.

23. Kirca, A. H., Jayachandran, S. and Bearden, W. O. (2005). Market Orientation: A Meta-Analytic Review and Assessment of Its Antecedents and Impact on Performance, Journal of Marketing, Vol. 69, No. 2, pp. 24-41.

24. Kohli, A. K. and Jaworski, B. J. (1990). Market Orientation: The Construct, Research Propositions, and Managerial Implications, Journal of Marketing, Vol. 54, No. 2, pp. 1-18.

25. Kohli, A. K., Jaworski, B. J. and Kumar, A. (1993). MARKOR: A Measure of Market Orientation, Journal of Marketing Research, Vol. 30, No. 4, pp. 467-477.

26. Lafferty, B. A., Tomas M. and Hult, G. (2001). A synthesis of contemporary market orientation perspectives, European Journal of Marketing, Vol. 35, No. 1/2, pp. 92109.

27. Levitt, T. (2004). Marketing myopia. 1960, Harvard Business Review, Vol. 82, No. 7-8, pp. 138-149.

28. Li, Q., Zhou, J., Mo, L., Yang, J. and An, X. (2009). Analysis on the Impact of Cooperation Between Independent Power Producer and the Grid Company in Day-Ahead Electricity Market, Proceedings - Power and Energy Engineering Conference, IEEE, Wuhan, China, Vol.1, pp.1-5.

29. Liao, S.-H., Chang, W.-J., Wu, C.-C. and Katrichis, J. M. (2011). A survey of market orientation research (1995-2008), Industrial Marketing Management, Vol. 40, No. 2, pp. 301-310. 
30. Maydeu Olivares, A. and Lado, N. (2003). Market orientation and business economic performance, International Journal of Service Industry Management, Vol. 14, No. 3, pp. 284-309.

31. Milisavljavić, M. (2005). Tržišna orijentacija i poslovni uspeh preduzeća, Megatrend Revija, Vol. 2, No. 2, pp. 151-165, Univerzitet “Džon Nezbit”, Beograd, Republika Srbija.

32. Mitchell, R. W., Wooliscroft, B. and Higham, J. (2010). Sustainable Market Orientation: A New Approach to Managing Marketing Strategy, Journal of Macromarketing, Vol. 30, No. 2, pp. 160-170.

33. Morgan, N. A., Vorhies, D. W. and Mason, C. H. (2009). Market orientation, marketing capabilities, and firm performance, Strategic Management Journal, Vol. 30, No. 8, pp. 909-920.

34. Narver, J. C. and Slater, S. F. (1990). The Effect of a Market Orientation on Business Profitability, Journal of Marketing, Vol. 54, No. 4, pp. 20-35.

35. Ngo, L. V. and O'Cass, A. (2012). Performance implications of market orientation, marketing resources, and marketing capabilities, Journal of Marketing Management, Vol. 28, No. 1-2, pp. 173-187.

36. Olavarrieta, S. and Friedmann, R. (2008). Market orientation, knowledge-related resources and firm performance, Journal of Business Research, Vol. 61, No. 6, pp. 623-630.

37. Pallant, J. (2011). SPSS Survival Manual (4th ed.), Allen \& Unwin, Crows Nest, New South Wales, Australia.

38. Panigyrakis, G. G. and Theodoridis, P. K. (2007). Market orientation and performance: An empirical investigation in the retail industry in Greece, Journal of Retailing and Consumer Services, Vol. 14, No. 2, pp. 137-149.

39. Pelham, A. M. (1997a). Mediating Influences on the Relationsmp between Market Orientation and Profitability in Small Industrial Firms, Journal of Marketing Theory and Practice, Vol. 5, No. 3, pp. 55-76.

40. Pelham, A. M. (1997b). Market orientation and performance: the moderating effects of product and customer differentiation, Journal of Business \& Industrial Marketing, Vol. 12, No. 5, pp. 276-296.

41. Pelham, A. M. (1999). Influence of Environment, Strategy, and Market Orientation on Performance in Small Manufacturing Firms, Journal of Business Research, Vol. 45, No. 1, pp. 33-46.

42. Pelham, A. M. and Wilson, D. T. (1996). A longitudinal study of the impact of market structure, firm structure, strategy, and market orientation culture on dimensions of small-firm performance, Journal of the Academy of Marketing Science, Vol. 24, No. 1, pp. 27-43.

43. Petz, B. (2004). Osnovne statističke metode za nematematičare, Naklada Slap, Zagreb, Hrvatska.

44. Protcko, E. and Dornberger, U. (2014). The impact of market orientation on business performance - the case of Tatarstan knowledge-intensive companies (Russia), Problems and Perspectives in Management, Vol. 12, No. 4, pp. 225-231. 
45. Raju, P. S., Lonial, S. C. and Crum, M. D. (2011). Market orientation in the context of SMEs: A conceptual framework, Journal of Business Research, Vol. 64, No. 12, pp. 1320-1326.

46. Raju, P. S., Lonial, S. C. and Gupta, Y. P. (1995). Market orientation and performance in the hospital industry, Journal of Health Care Marketing, Vol. 15, No. 4, pp. 34-41.

47. Rapp, A., Beitelspacher, L. S., Schillewaert, N. and Baker, T. L. (2012). The differing effects of technology on inside vs. outside sales forces to facilitate enhanced customer orientation and interfunctional coordination, Journal of Business Research, Vol. 65, No. 7, pp. 929-936.

48. Rodriguez Cano, C., Carrillat, F. A. and Jaramillo, F. (2004). A meta-analysis of the relationship between market orientation and business performance: evidence from five continents, International Journal of Research in Marketing, Vol. 21, No. 2, pp. 179-200.

49. Ruekert, R. W. (1992). Developing a market orientation: An organizational strategy perspective, International Journal of Research in Marketing, Vol. 9, No. 3, pp. 225 245.

50. Salavou, H. (2002). Profitability in market-oriented SMEs: does product innovation matter? European Journal of Innovation Management, Vol. 5, No. 3, pp. 164-171.

51. Shoham, A., Rose, G. M. and Kropp, F. (2005). Market orientation and performance: a meta-analysis, Marketing Intelligence \& Planning, Vol. 23, No. 5, pp. 435-454.

52. Slater, S. F. and Narver, J. C. (1994). Does Competitive Environment Moderate the Market Orientation-Performance Relationship?, Journal of Marketing, Vol. 58, No. 1, 46-55.

53. Stanković, L., Đukić, S. and Popović, A. (2013): Tržišna orijentacija preduzeća u Srbiji kao determinanta njihove inovativnosti i konkurentnosti. In N. Janićijević \& S. Lovreta (Eds.), Konkurentnost preduzeća u Srbiji, pp. 147-166, CID, Beograd, Republika Srbija.

54. Takata, H. (2016). Effects of industry forces, market orientation, and marketing capabilities on business performance: An empirical analysis of Japanese manufacturers from 2009 to 2011, Journal of Business Research, Vol. 69, No. 12, pp. 5611-5619.

55. Willer, H. and Lernoud, J. (2014). The World of Organic Agriculture. Statistics and Emerging Trends 2014, Research Institute of Organic Agriculture (FiBL), Frick, and International Federation of Organic Agriculture Movements (IFOAM), Bonn, Germany.

56. Willer, H. and Lernoud, J. (2017). The World of Organic Agriculture. Statistics and Emerging Trends 2017, Research Institute of Organic Agriculture (FiBL), Frick, and International Federation of Organic Agriculture Movements (IFOAM), Bonn, Germany 


\title{
UTICAJ TRŽIŠNE ORIJENTACIJE NA POSLOVNE PERFORMANSE PROIZVOĐAČA ORGANSKE HRANE IZ SRBIJE
}

\author{
Semir Vehapi ${ }^{5}$, Marina Milanovic $^{6}$
}

\begin{abstract}
Rezime
U savremenim uslovima tržišna orijentacija ima vitalnu ulogu u generisanju superiornih performansi i kreiranju konkurentske prednosti. Mada je koncept tržišne orijentacije bio izučavan u različitim studijama, postoji jako malo takvih istraživanja u kontekstu srpske privrede, dok u kontekstu industrije organske hrane gotovo i da ih nema. Stoga je osnovni cilj rada da istraži stepen prihvatanja tržišne orijentacije u poslovanju proizvođača organske hrane u Srbiji $i$ da identifikuje vezu između njihove tržišne orijentacije $i$ poslovnih performansi. U radu je primenjena kulturološka perspektiva u merenju tržišne orijentacije korišćenjem MKTOR skale kao osnove. Na uzorku od 42 anketirana proizvođača, potvrđeno je da elementi tržišne orijentacije direktno i pozitivno utiču na rast prodaje, tržišno učešće i profitabilnost, kao i na ukupne poslovne performanse.
\end{abstract}

Ključne reči: tržišna orijentacija, poslovne performanse, proizvođači, organska hrana, Srbija.

5 Dr Semir Vehapi, Asistent, Državni univerzitet u Novom Pazaru, Departman za Ekonomske nauke (Kabinet br. 23), Ulica Vuka Karadžića bb, 36300 Novi Pazar, Republika Srbija, Telefon: +381638618 381, E-mail: svehapi@np.ac.rs

6 Mr Marina Milanović, Doktorand, Ekonomski fakultet u Nišu, Ulica Dr Jovana Ristića 84, 34000 Kragujevac, tel: +381659393777, e-mail: milanovicm.ar67@gmail.com 
ECONOMICS OF

AGRICULTURE

\section{CONTENT}

1. Adriana Radosavac, Desimir Knežević

ECONOMIC IMPORTANCE OF USE

OF PESTICIDES IN WHEAT PRODUCTION . . . . . . . . . . . 1323

2. Berhe Gebregewergs, Muuz Hadush

DOES CLIMATE CHANGE AFFECT PRICE OF VEGETABLES:

EVIDENCE FROM TIGRAI, NORTHERN MOST ETHIOPIA. . . . .1335

3. Grujica Vico, Aleksandra Govedarica-Lučić, Zoran Rajić, Radomir Bodiroga, Ivan Mičić, Silvija Zec Sambol, Marija Mičić

MULTI ATTRIBUTE ASSESSMENT APPROACH

IN VEGETABLE PRODUCTION . . . . . . . . . . . . . . 1355

4. Igor Trandafilović, Vesna Conić, Aleksandra Blagojević

IMPACT OF DEMOGRAPHIC FACTORS ON

ENVIRONMENTALLY CONSCIOUS PURCHASE BEHAVIOUR. . .1365

5. Imre Milán Harcsa

STUDY ON THE POTENTIAL OF SUBCONTRACT

PALINKA DISTILLATION . . . . . . . . . . . . . . 1379

6. Jelena Andrašić, Vera Mirović, Nada Milenković, Branimir Kalaš, Miloš Pjanić

IMPACT OF TAKEOVER PROCESS ON EMPLOYEES -

EVIDENCE FROM FOOD, RETAIL AND FINANCIAL SECTOR . . .1393

7. Jelena Birovljev, Danilo Đokić, Bojan Matkovski, Žana Kleut

ECONOMIC PERFORMANCES OF AGRICULTURE

OF CEFTA AND FORMER CEFTA COUNTRIES . . . . . . . . . . 1413

8. Jelena Marković, Svetlana Stevović

SUSTAINABILITY OF CHEMICAL SOIL QUALITY

IN SOUTHERN MORAVA RIVER VALLEY

IN CORELLATION WITH THE FLOODING $\ldots \ldots \ldots \ldots \ldots$ 
9. Mile Peševski, Zoran Milovančević

THE CHANGES IN THE USAGE OF AGRICULTURAL LAND

IN EASTERN REGION OF REPUBLIC OF MACEDONIA

BETWEEN $1991-2030 \ldots \ldots$. . . . . . . . . . . . . . . . . . . . . . .

10. Odjuvwuederhie Emmanuel Inoni, 'Oraye Dicta Ogisi, Felix Odemero Achoja

PROFITABILITY AND TECHNICAL EFFICIENCY IN HOMESTEAD

CATFISH PRODUCTION IN DELTA STATE, NIGERIA . . . . . . . 1449

11. Olja Munitlak - Ivanović, Jovan Zubović, Petar Mitić

RELATIONSHIP BETWEEN SUSTAINABLE DEVELOPMENT AND

GREEN ECONOMY - EMPHASIS ON GREEN FINANCE

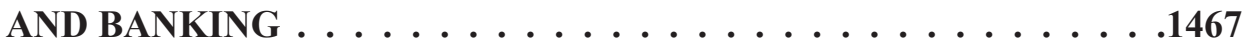

12. Petar Munćan, Dragica Božić

FARM SIZE AS A FACTOR OF EMLOYMENT AND INCOME

OF MEMBERS OF FAMILY FARMS . . . . . . . . . . . . . 1483

13. Rade Popović, Mira Kovljenić

EFFICIENCY OF WHEAT PRODUCTION ON FARMS

IN THE REPUBLIC OF SERBIA . . . . . . . . . . . . . . . . . . . . . . . . .

14. Radovan Damnjanović, Snežana Krstić, Milena Knežević, Svetislav Stanković,

Dejan Jeremić

THE DISCRIMINANT ANALYSIS APPLIED TO THE

DIFFERENTIATION OF SOIL TYPES . . . . . . . . . . . . 1513

15. Slavica Otović, Dunja Demirović, Kristina Košić, Aleksandra Vujko

FOSTERING ENTERPRENUERSHIP AT HIGH SCHOOLS:

A CASE OF RURAL AREAS IN VOJVODINA (SERBIA) . . . . . . .1523

16. Vladimir Ilić, Ivan Bauer, Anastazija Tanja Đelić, Aleksandar Nešković

INSTITUTIONAL SUPPORT FOR STRENGTHENING

ENTREPRENEURSHIP IN AGRICULTURAL PRODUCTION

OF THE REPUBLIC OF SERBIA . . . . . . . . . . . . . . . . . . . . . . . .

17. Boro Krstić, Zorica Vasiljević, Miroslav Nedeljković

INSURANCE CONTRACT AS THE BASIS FOR THE SAFETY OF

AGRICULTURAL PRODUCERS IN THE REPUBLIC OF SRPSKA • . 1555

18. Dejan Sekulić, Aleksandar Petrović, Vladimir Dimitrijević

WHO ARE WINE TOURISTS? AN EMPIRICAL INVESTIGATION

OF SEGMENTS IN SERBIAN WINE TOURISM . . . . . . . . . . . . . 
19. Milan Beslać, Ćorić Goran

FINANCIAL AND PRODUCTION ASPECTS OF GENETICALLY MODIFIED ORGANISMS $\ldots \ldots \ldots \ldots \ldots \ldots \ldots \ldots \ldots$

20. Mlađan Maksimović, Darjan Karabašević, Miodrag Brzaković, Pavle Brzaković THE EFFECTS RESULTING FROM THE APPLICATION OF THE CONCEPT OF THE SUSTAINABLE DEVELOPMENT OF RURAL TOURISM ON STARA PLANINA . . . . . . . . . . . . . . . .1595

21. Vesna Popović, Predrag Vuković, Milivoje Ćosić FOOD SAFETY AND QUALITY POLICY IN THE REPUBLIC OF SERBIA . . . . . . . . . . . . . . . . 1607

22. Radovan Pejanović, Danica Glavaš-Trbić, Mirela Tomaš-Simin PROBLEMS OF AGRICULTURAL AND RURAL DEVELOPMENT IN SERBIA AND NECESSITY OF NEW AGRICULTURAL POLICY . . . .1619

23. Saša Marković, Slavoljub Vujović, Aleksandar Damnjanović MARKETING AND HIGHER EDUCATION CONDITION IN SERBIA . . . . . . . . . . . . . . . . 1635

24. Semir Vehapi, Marina Milanović THE EFFECT OF MARKET ORIENTATION ON BUSINESS PERFORMANCE OF SERBIAN ORGANIC PRODUCERS . . . . . 1651

25. Suad Bećirović, Šemsudin Plojović, Enis Ujkanović, Senadin Plojović CHALLENGES AT STARTING AN AGRIBUSINESS IN THE HILLY MOUNTAINOUS REGIONS OF SOUTHWEST SERBIA . . . . . . . .1669

26. Vladimir Zakić, Vlado Kovačević, Jelena Damnjanović SIGNIFICANCE OF FINACIAL LITERACY FOR THE AGRICULTURAL HOLDINGS IN SERBIA . . . . . . . . . . 1687

27. Željko Bjelajac, Marijana Dukić Mijatović, Željko Vojinović PROTECTION OF LAND IN THE REPUBLIC OF SERBIA AND ECOLOGICAL SECURITY WITH REGARD TO STRATEGIC AND LEGAL FRAMEWORKS . . . . . . . . . .1703 